Available online at https://ojs.unud.ac.id/index.php/bse/index

Vol. 26 No. 2, Agustus 2021, pages: 177-192

ISSN : $1410-4628$

e-ISSN: $\underline{2580-5312}$

\title{
PENGARUH ORIENTASI PASAR DAN INOVASI TERHADAP KEUNGGULAN BERSAING DAN KINERJA PEMASARAN
}

\section{Putu Aryanti Putri Kencana1 ${ }^{1}$ Gusti Ayu Ketut Giantari ${ }^{2}$}

Article history:

Submitted:

28 Maret 2021

Revised:

22 April 2021

Accepted:

24 April 2021

\section{Keywords:}

Market Orientation, Innovation, Competitive Advantage, Marketing Performance

\section{Kata Kunci:}

Orientasi Pasar, Inovasi, Keunggulan Bersaing, Kinerja Pemasaran

\section{Koresponding:}

Fakultas Ekonomi dan Bisnis Universitas Udayana, Bali, Indonesia

Email:

aryanthiputri01@gmail.com

\section{Abstract}

The purpose of this research is to explain the influence of market orientation and innovation on competitive advantages and marketing performance on apparel MSMEs in Denpasar City. This research was conducted in MSME apparel located in Denpasar city with a sample of 50 MSMEs using purposive sampling sample determination method. Data collection using questionnaires. The data were analyzed using PLS-based SEM analysis techniques. The results of this study showed that market orientation has a positive and significant effect on marketing performance, innovation positively and significantly affects marketing performance, market orientation has a positive and significant effect on competitive excellence, innovation positively and significantly affects competitive excellence, competitive advantage has a positive and significant effect on marketing performance.

\footnotetext{
Abstrak

Tujuan penelitian ini adalah menjelaskan pengaruh orientasi pasar dan inovasi terhadap keunggulan bersaing dan kinerja pemasaran pada UMKM pakaian jadi. Penelitian ini dilakukan di UMKM pakaian jadi yang berada di Kota Denpasar dengan sampel sebanyak 50 UMKM menggunakan metode penentuan sampel purposive sampling. Pengumpulan data menggunakan kuesioner. Data dianalisis menggunakan teknik analisis SEM berbasis PLS. Hasil penelitian ini menunjukkan bahwa orientasi pasar berpengaruh secara positif dan signifikan terhadap kinerja pemasaran, inovasi berpengaruh secara positif dan signifikan terhadap kinerja pemasaran, orientasi pasar berpengaruh secara positif dan signifikan terhadap keunggulan bersaing, inovasi berpengaruh secara positif dan signifikan terhadap keunggulan bersaing, keunggulan bersaing berpengaruh secara positif dan signifikan terhadap kinerja pemasaran.
}

Fakultas Ekonomi dan Bisnis Universitas Udayana, Bali, Indonesia ${ }^{2}$ 
Pengaruh Orientasi Pasar dan Inovasi Terhadap ...

Putu Aryanti Putri Kencana \& I Gusti Ayu Ketut Giantari

\section{PENDAHULUAN}

Industri pakaian jadi ialah industri penting yang secara ekonomi menimbulkan dampak yang baik dalam penyerapan tenaga kerja dan sumbangan nilai tambah terhadap PDB Indonesia. Industri pakaian jadi ialah tipe industri yang masuk dalam rangkaian Industri Tekstil dan Produk Tekstil (TPT) dari hulu ke hilir (Rayadiani, 2015). Peraturan Presiden Republik Indonesia No 28 Tahun 2008 tentang Kebijakan Industri Nasional serta Peraturan Menteri Perindustrian Republik Indonesia No 109/ M- IND/ PER/ 10/ 2009 tentang Peta Panduan (Road Map) Pengembangan Klaster Industri Tekstil serta Produk Tekstil, melaporkan bahwa pemerintah sudah menetapkan industri pakaian jadi menjadi salah satu klaster industri prioritas berbasis industri manufaktur yang dibesarkan oleh pemerintah.

Pertumbuhan industri pakaian jadi di Indonesia menunjukkan angka yang baik. Kementerian Perindustrian Republik Indonesia (2019) menyatakan bahwa industri pakaian jadi segmen besar dan sedang mengalami pertumbuhan produksi paling tinggi di antara sektor lainnya pada kuartal I/2019. Pertumbuhan industri pakaian jadi di Bali khususnya kota Denpasar juga mendominasi dibandingkan dengan industri lainnya. Pada tahun 2019, industri pakaian jadi di Kota Denpasar tumbuh sebesar 21,19 persen, disusul dengan industri pengolahan lainnya, tumbuh 17,59 persen. Industri kayu, barang dari kayu, gabus (tidak termasuk furniture) dan barang dari anyaman bambu, rotan dan sejenisnya mengalami pertumbuhan 14,79 persen, serta industri makanan tumbuh
10,28 persen. Pertumbuhan tersebut merupakan pertumbuhan volume produksi karena adanya peningkatan volume permintaan akan pakaian jadi (Denpasarkota.go.id, 2019).

Peningkatan impor pakaian jadi menjadi tantangan besar untuk pelaku usaha pakaian jadi. Berdasarkan artikel yang dilansir dari CNBC Indonesia (2019), Komite Pengamanan Perdagangan Indonesia (KPPI) tahun 2019 melakukan investigasi terhadap pengamanan perdagangan terkait lonjakan volume impor produk pakaian jadi asal China. Menurut KPPI, tingginya impor produk pakaian jadi dari China tersebut dianggap merugikan industri dalam negeri. Persaingan dengan produk impor juga merupakan isu penting yang berhubungan dengan produk pakaian jadi, mengingat kondisi Indonesia dengan jumlah penduduk yang lebih dari 250 juta menjadi target pasar yang potensial.

Semakin tingginya tingkat persaingan dan kemajuan teknologi menyebabkan suatu produk akan tumbuh sampai pada suatu titik dimana produk tersebut akan terlihat serupa dan tidak dapat dibedakan dari produk lainnya (Mulyani \& Mudiantono, 2015). Produsen harus memiliki keunggulan bersaing yang merupakan ciri khas dari produknya sehingga mampu bersaing. Keunggulan bersaing dari suatu produk dapat dibentuk dengan melakukan inovasi serta mendekatkan diri pada pasar sehingga kinerja khususnya kinerja pemasaran dapat meningkat dan perusahaan mampu mempertahankan eksistensinya di pasar.

Kinerja pemasaran adalah ukuran prestasi menyeluruh dalam perusahaan yang 
Pengaruh Orientasi Pasar dan Inovasi Terhadap ...

Putu Aryanti Putri Kencana \& I Gusti Ayu Ketut Giantari

terkait dengan aktivitas proses pemasaran. Kinerja pemasaran merupakan suatu konsep yang digunakan untuk mengukur prestasi pasar yang telah dicapai oleh suatu produk yang dihasilkan perusahaan (Sugiyarti, 2015). Kunci penting untuk memenangkan persaingan terletak pada kemampuan perusahaan untuk menciptakan keunggulan bersaing dengan memahami kebutuhan pasar dan terus melakukan inovasi-inovasi sehingga produk yang dihasilkan sejalan dengan perkembangan dan kebutuhan pasar. Inovasi merupakan proses untuk mengubah sebuah peluang menjadi ide yang dapat dipasarkan. Suatu perusahaan dapat memperoleh manfaat yang lebih besar jika mereka mengembangkan, berkomunikasi, dan mengeksplorasi inovasi yang sesuai dengan pasar (Udriyah et al., 2019).

Orientasi pasar ialah perencanaan strategis unit bisnis untuk memenuhi tuntutan pasar dengan memperhatikan semua fungsi pada perusahaan yang mampu menyerap informasi penting terkait hal yang mempengaruhi pembelian, strategi pengambilan keputusan antar fungsional dan antar divisi melaksanakan kegiatan pemasaran (Herman et al., 2018). Hasil penelitian yang dilakukan oleh Rokhman (2019) menyatakan bahwa orientasi pasar mampu meningkatkan kinerja pemasaran melalui keunggulan bersaing. Hasil penelitian yang dilakukan oleh Udriyah et al., (2019) menyatakan bahwa orientasi pasar dan inovasi memberikan pengaruh pada keunggulan bersaing dan kinerja pemasaran, begitu pula hasil penelitian yang dilakukan oleh Satwika \& Dewi (2018) menyatakan bahwa orientasi pasar dan inovasi mampu untuk meningkatkan keunggulan bersaing dan kinerja pemasaran. Penelitian dengan hasil yang berbeda dilakukan oleh Jaworski \& Kohli (1993) menyatakan bahwa orientasi pasar tidak memiliki pengaruh yang signifikan terhadap kinerja. Penelitian yang dilakukan Setyawati \& Abrilia (2013) juga menyatakan bahwa orientasi pasar tidak memiliki pengaruh terhadap kinerja. Adapun hipotesis pada penelitian ini, yaitu:

$\mathrm{H}_{1}$ : orientasi pasar berpengaruh positif dan signifikan terhadap kinerja pemasaran.

$\mathrm{H}_{2}$ : inovasi berpengaruh positif dan signifikan terhadap kinerja pemasaran.

$\mathrm{H}_{3}$ : orientasi pasar berpengaruh positif dan signifikan terhadap keunggulan bersaing.

$\mathrm{H}_{4}$ : inovasi berpengaruh positif dan signifikan terhadap keunggulan bersaing.

$\mathrm{H}_{5}$ : keunggulan bersaing berpengaruh positif dan signifikan terhadap kinerja pemasaran.

\section{METODE PENELITIAN}

Hubungan antar variabel yang diuji pada penelitian ini yaitu variabel orientasi pasar, inovasi, keunggulan bersaing, dan kinerja pemasaran khususnya pada UMKM pakaian jadi di Kota Denpasar, sehingga penelitian ini merupakan penelitian yang bersifat asosiatif. Penelitian ini dilakukan pada UMKM pakaian jadi di Kota Denpasar, dengan objek orientasi pasar, inovasi, keunggulan bersaing, dan kinerja pemasaran. 
Pengaruh Orientasi Pasar dan Inovasi Terhadap ...

Putu Aryanti Putri Kencana \& I Gusti Ayu Ketut Giantari

Variabel eksogen dalam penelitian ini adalah orientasi pasar (X1) dan inovasi (X2). Indikator orientasi pasar pada penelitian ini mengadaptasi dan memodifikasi penelitian sebelumnya yang telah dilakukan oleh Dewi, (2006); Zhou et al., (2009); Safarnia et al., (2011); Zhang \& Bruning (2011); Lo et al., (2015); Ulya (2019) yaitu orientasi pelanggan, orientasi pesaing, dan koordinasi antar fungsi. Indikator inovasi pada penelitian ini mengadaptasi dan memodifikasi penelitian yang sudah dilakukan sebelumnya oleh Asashi \& Sukaatmadja (2017); Alwi \& Handayani (2018); Herman et al., (2018) yaitu pengembangan kualitas produk, perubahan desain, dan daya kreatifitas. Variabel endogen dalam penelitian ini adalah keunggulan bersaing (Y1) dan kinerja pemasaran (Y2). Indikator keunggulan bersaing pada penelitian ini mengadaptasi dan memodifikasi penelitian yang telah dilakukan sebelumnya oleh Hartanty \& Ratnawati (2013); Alwi \& Handayani (2018); Udriyah et al., (2019) yaitu kualitas produk, harga bersaing, dan diferensiasi. Indikator kinerja pemasaran pada penelitian ini mengadaptasi dan memodifikasi dari penelitian sebelumnya yang dilakukan oleh Hartanty \& Ratnawati (2013); Udriyah et al., (2019); Ginting et al., (2020) yaitu volume penjualan, pertumbuhan pelanggan, kemampulabaan, dan hubungan dengan pelanggan.

Data kuantiatif pada penelitian ini diperoleh dari tabulasi hasil kuesioner yang disebarkan kepada para responden penelitian ini, serta data kualitatif yang diperoleh dari sejarah singkat, kegiatan usaha, dan jawaban atau pendapat yang diberikan oleh responden melalui kuesioner mengenai variabel penelitian yaitu kinerja pemasaran, keunggulan bersaing, inovasi, dan orientasi pasar pada UMKM pakaian jadi di Kota Denpasar.

Data primer dalam penelitian ini diperoleh langsung dari pengelola UMKM pakaian jadi di Kota Denpasar melalui jawaban atau skor terhadap variabel-variabel penelitian dalam kuesioner yang dijawab langsung oleh responden, sedangkan data sekunder dalam penelitian ini diperoleh dengan mengumpulkan data informasi seperti jurnal-jurnal, buku referensi, serta informasi yang terkait dengan penelitian mengenai pakaian jadi dan UMKM pakaian jadi.

Populasi dalam penelitian ini adalah UMKM pakaian jadi yang berlokasi di Kota Denpasar. Sampel yang digunakan sebanyak 50 pemilik atau pengelola UMKM pakaian jadi. Metode yang digunakan dalam penentuan sampel adalah metode purposive sampling, yaitu sampel ditentukan berdasarkan kriteria. Adapun kriteria yang digunakan dalam penelitian ini yaitu pendidikan terakhir minimal SMA/SMK, responden merupakan pemilik atau pengelola UMKM pakaian jadi di Kota Denpasar, responden sudah berkecimpung dalam bisnis pakaian jadi minimal 6 bulan saat penelitian ini dilakukan.

Pengujian instrumen penelitian menggunakan uji validitas dan uji reliabilitas instrumen, teknik analisis data yang digunakan dalam penelitian ini yaitu analisis statistik deskriptif, analisis statistik inferensial dengan menggunakan Structural Equation Modeling (SEM) berbasis Partial Least Square (PLS). 


\section{HASIL DAN PEMBAHASAN}

Tabel 1.

Karakteristik Responden

\begin{tabular}{clccc}
\hline No & Variabel & Klasifikasi & Jumlah (orang) & Persentase (\%) \\
\hline \multirow{2}{*}{1} & \multirow{2}{*}{ Jenis Kelamin } & Laki - Laki & 26 & 52 \\
& & Perempuan & 24 & 48 \\
& Jumlah & $20-25$ Tahun & 50 & 100 \\
\hline \multirow{2}{*}{2} & \multirow{2}{*}{ Usia } & 26-30 Tahun & 14 & 28 \\
& & $31-35$ Tahun & 25 & 50 \\
& \multirow{3}{*}{ Jumlah } & $>35$ Tahun & 7 & 8 \\
& \multirow{3}{*}{3} & & 4 & 100 \\
& Pendidikan & SMA/SMK & 50 & 18 \\
& terakhir & Diploma & 9 & 18 \\
& & Sarjana & 9 & 62 \\
& \multirow{2}{*}{ Jumlah } & Pasca Sarjana & 31 & 2 \\
\end{tabular}

\section{Sumber: Data diolah, 2020}

Tabel 1 menunjukkan bahwa jumlah pengusaha UMKM pakaian jadi di Kota Denpasar yang dijadikan sampel sebanyak 50 orang. Pengusaha UMKM pakaian jadi di Kota Denpasar mayoritas adalah laki-laki dengan rentang usia 26-30 tahun dengan tingkat pendidikan yang cenderung tinggi yaitu sarjana. Hal ini mengindikasikan lakilaki lebih berniat melakukan usaha dibidang pakaian jadi ketimbang perempuan karena laki-laki cenderung lebih berani dalam mengambil resiko. Rentang usia 26-30 tahun adalah usia yang produktif mendukung kegiatan mereka.

Tabel 2.

Hasil Penilaian Responden Terhadap Variabel Orientasi Pasar

\begin{tabular}{|c|c|c|c|c|c|c|c|c|c|}
\hline \multirow[t]{2}{*}{ No } & \multirow[t]{2}{*}{ Pernyataan } & \multicolumn{5}{|c|}{$\begin{array}{l}\text { Proporsi Jawaban } \\
\text { Responden (Orang) }\end{array}$} & \multirow[t]{2}{*}{ Jumlah } & \multirow{2}{*}{$\begin{array}{l}\text { Rata- } \\
\text { rata }\end{array}$} & \multirow[t]{2}{*}{ Kriteria } \\
\hline & & 1 & 2 & 3 & 4 & 5 & & & \\
\hline 1 & $\begin{array}{l}\text { Kami selalu berusaha menyediakan apa yang } \\
\text { pelanggan inginkan dan butuhkan }\end{array}$ & 0 & 14 & 7 & 25 & 4 & 169 & 3.38 & $\begin{array}{l}\text { Cukup } \\
\text { Baik }\end{array}$ \\
\hline 2 & $\begin{array}{l}\text { Kami memberikan produk dan layanan terbaik } \\
\text { sehingga pelanggan selalu merasa puas }\end{array}$ & 0 & 14 & 9 & 18 & 9 & 172 & 3.44 & Baik \\
\hline 3 & $\begin{array}{l}\text { Kami berusaha untuk konsisten terhadap produk } \\
\text { dan layanan kami yang sudah dianggap baik di } \\
\text { mata pelanggan sehingga pelanggan akan bersikap } \\
\text { loyal }\end{array}$ & 0 & 14 & 7 & 12 & 17 & 182 & 3.64 & Baik \\
\hline 4 & $\begin{array}{l}\text { Kami secara teratur melakukan analisis terhadap } \\
\text { kelemahan dan kelebihan yang dimiliki oleh } \\
\text { pesaing }\end{array}$ & 2 & 12 & 7 & 26 & 3 & 166 & 3.32 & $\begin{array}{l}\text { Cukup } \\
\text { Baik }\end{array}$ \\
\hline
\end{tabular}


Pengaruh Orientasi Pasar dan Inovasi Terhadap ...

Putu Aryanti Putri Kencana \& I Gusti Ayu Ketut Giantari

\section{Lanjutan}

Tabel 2.

Hasil Penilaian Responden Terhadap Variabel Orientasi Pasar

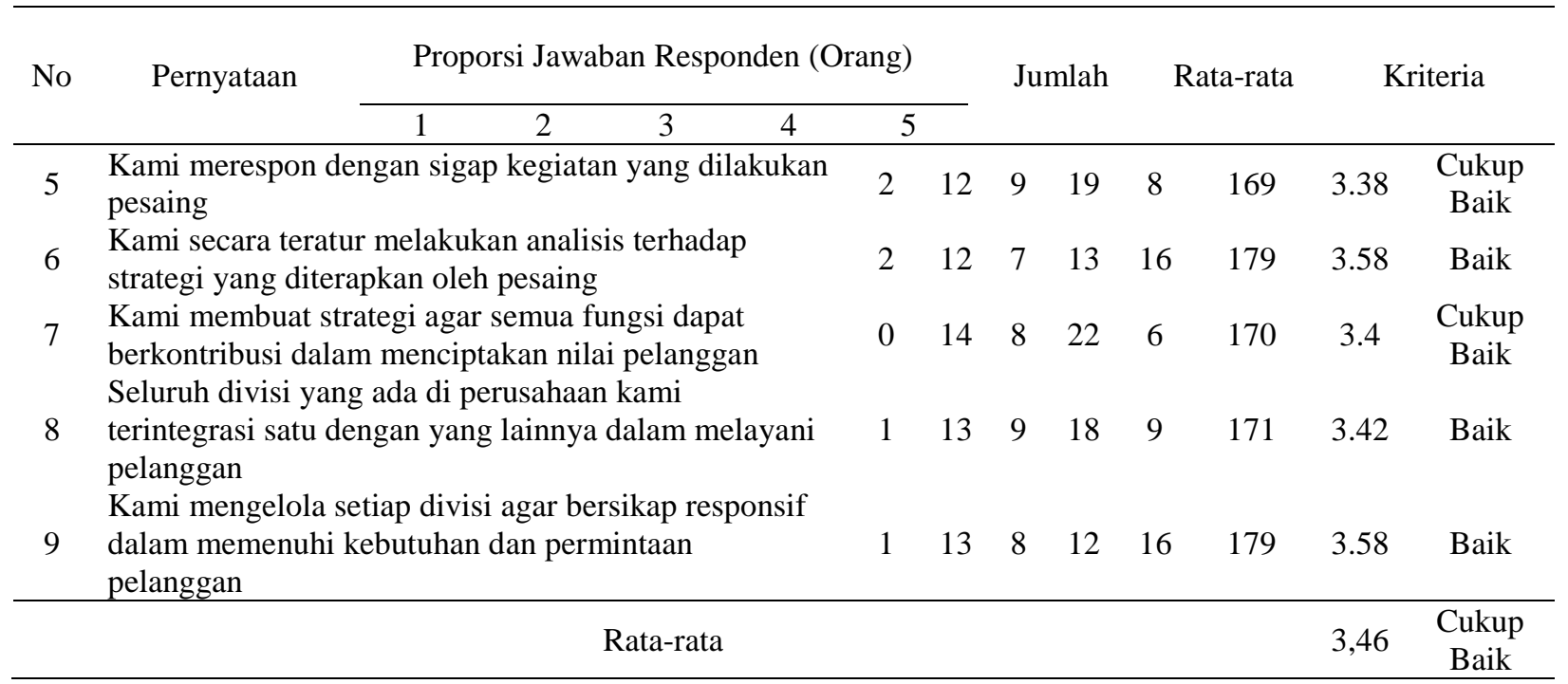

Sumber: Data diolah, 2020

Pada Tabel 2 dikatakan bahwa secara keseluruhan responden setuju terhadap penilaian variabel orientasi pasar hal ini ditandai dengan rata-rata skor keseluruhan 3,46 sehingga dapat dikatakan sudah cukup baik. Variabel orientasi pasar yang mempunyai nilai paling rendah ada pada pernyataan "kami secara teratur melakukan analisis terhadap kelemahan dan kelebihan yang dimiliki oleh pesaing", dengan nilai rata-rata 3,32 yang berarti secara umum responden menganggap belum secara teratur melakukan analisis terhadap kelemahan dan kelebihan yang dimiliki oleh pesaing. Variabel orientasi pasar yang mempunyai nilai paling tertinggi ada pada pernyataan "kami berusaha untuk konsisten terhadap produk dan layanan kami yang sudah dianggap baik di mata pelanggan sehingga pelanggan akan bersikap loyal", dengan nilai rata-rata 3,64 yang artinya secara umum responden menganggap konsisten terhadap produk dan layanan sudah membuat pelanggan bersikap loyal.

Lingkungan bisnis yang berubah mewajibkan perusahaan untuk mampu menciptakan ide baru dan menawarkan produk-produk inovatif. Inovasi yang tinggi akan meningkatkan kemampuan perusahaan untuk menciptakan produk yang berkualitas. Tabel 3 menunjukkan bahwa secara umum responden setuju terhadap penilaian variabel inovasi dengan skor rata-rata keseluruhan yaitu 3,31 sehingga dapat dikatakan sudah cukup baik. Variabel inovasi yang mempunyai nilai paling rendah ada pada pernyataan "kami selalu berusaha mengembangkan produk kami lebih baik lagi”, dengan nilai rata-rata sebesar 3,24 yang artinya secara umum responden menganggap belum berusaha mengembangkan produk kami lebih baik lagi. 
Tabel 3.

Penilaian Responden Terhadap Variabel Inovasi

\begin{tabular}{|c|c|c|c|c|c|c|c|c|c|}
\hline \multirow[t]{2}{*}{ No } & \multirow[t]{2}{*}{ Pernyataan } & \multicolumn{5}{|c|}{$\begin{array}{l}\text { Proporsi Jawaban } \\
\text { Responden (Orang) }\end{array}$} & \multirow[t]{2}{*}{ Jumlah } & \multirow{2}{*}{$\begin{array}{c}\text { Rata- } \\
\text { rata }\end{array}$} & \multirow[t]{2}{*}{ Kriteria } \\
\hline & & 1 & 2 & 3 & 4 & 5 & & & \\
\hline 1 & $\begin{array}{l}\text { Kami selalu berusaha mengembangkan produk } \\
\text { kami lebih baik lagi }\end{array}$ & 1 & 15 & 11 & 17 & 6 & 162 & 3.24 & $\begin{array}{l}\text { Cukup } \\
\text { Baik }\end{array}$ \\
\hline 2 & $\begin{array}{l}\text { Kami melakukan perubahan desain seiring } \\
\text { perkembangan mode yang sejalan dengan } \\
\text { permintaan konsumen }\end{array}$ & 1 & 16 & 10 & 14 & 9 & 164 & 3.28 & $\begin{array}{l}\text { Cukup } \\
\text { Baik }\end{array}$ \\
\hline 3 & $\begin{array}{l}\text { Kami memanfaatkan kreativitas yang dimiliki } \\
\text { untuk menciptakan produk-produk yang diminati } \\
\text { konsumen }\end{array}$ & 0 & 14 & 9 & 20 & 7 & 170 & 3.4 & $\begin{array}{l}\text { Cukup } \\
\text { Baik }\end{array}$ \\
\hline & Rata-rata & & & & & & & 3,31 & $\begin{array}{l}\text { Cukup } \\
\text { Baik }\end{array}$ \\
\hline
\end{tabular}

Sumber: Data diolah, 2020

Variabel inovasi yang memiliki nilai paling tinggi ada pada pernyataan "kami memanfaatkan kreativitas yang dimiliki untuk menciptakan produk-produk yang diminati konsumen", dengan nilai rata-rata 3,40 yang artinya secara umum para responden memanfaatkan kreativitas yang dimiliki untuk menciptakan produk-produk yang diminati konsumen.

Tabel 4.

Penilaian Responden Terhadap Variabel Keunggulan Bersaing

\begin{tabular}{|c|c|c|c|c|c|c|c|c|c|}
\hline \multirow[t]{2}{*}{ No } & \multirow[t]{2}{*}{ Pernyataan } & \multicolumn{5}{|c|}{$\begin{array}{l}\text { Proporsi Jawaban } \\
\text { Responden (Orang) }\end{array}$} & \multirow[t]{2}{*}{ Jumlah } & \multirow{2}{*}{$\begin{array}{l}\text { Rata- } \\
\text { rata }\end{array}$} & \multirow[t]{2}{*}{ Kriteria } \\
\hline & & 1 & 2 & 3 & 4 & 5 & & & \\
\hline 1 & $\begin{array}{l}\text { Kami selalu memastikan bahwa produk yang } \\
\text { kami jual memiliki kualitas yang terjamin }\end{array}$ & 4 & 12 & 9 & 18 & 7 & 162 & 3.24 & $\begin{array}{l}\text { Cukup } \\
\text { Baik }\end{array}$ \\
\hline 2 & $\begin{array}{l}\text { Produk kami memiliki harga yang dapat } \\
\text { bersaing dengan produk serupa }\end{array}$ & 3 & 11 & 10 & 23 & 3 & 162 & 3.24 & $\begin{array}{l}\text { Cukup } \\
\text { Baik }\end{array}$ \\
\hline 3 & $\begin{array}{l}\text { Kami berusaha membangun ciri khas yang } \\
\text { membedakan produk kami dari pesaing. }\end{array}$ & 3 & 11 & 7 & 26 & 3 & 165 & 3.3 & $\begin{array}{l}\text { Cukup } \\
\text { Baik }\end{array}$ \\
\hline & Rata-rata & & & & & & & 3,26 & $\begin{array}{l}\text { Cukup } \\
\text { Baik }\end{array}$ \\
\hline
\end{tabular}

Sumber: Data diolah, 2020

Keunggulan bersaing adalah sebuah situasi dimana suatu organisasi mampu mempertahankan posisinya dipasar selama pesaing tetap ada. Keunggulan bersaing dapat diperoleh dari kemampuan strategis dimana perusahaan memilih untuk bersaing di pasar yang ditargetkan (Russell \& Millar, 2014).
Tabel 4 menunjukkan bahwa secara umum responden setuju terhadap penilaian variabel keunggulan bersaing. Hal ini ditandai dengan skor rata-rata keseluruhan yaitu 3,26 yang artinya cukup baik. Variabel keunggulan bersaing yang mempunyai nilai paling rendah ada pada pernyataan "kami selalu memastikan 
Pengaruh Orientasi Pasar dan Inovasi Terhadap ...

Putu Aryanti Putri Kencana \& I Gusti Ayu Ketut Giantari

bahwa produk yang kami jual memiliki kualitas yang terjamin dan produk kami memiliki harga yang dapat bersaing dengan produk serupa", dengan nilai rata-rata 3,24 yang artinya secara keseluruhan responden menganggap belum memastikan bahwa produk yang mereka jual memiliki kualitas yang terjamin dan produk mereka memiliki harga yang dapat bersaing dengan produk serupa. Variabel keunggulan bersaing yang mempunyai nilai paling tinggi ada pada pernyataan "kami berusaha membangun ciri khas yang membedakan produk kami dari pesaing", dengan nilai rata-rata 3,30 yang artinya secara menyeluruh responden berusaha membangun ciri khas yang membedakan produk kami dari pesaing.

Tabel 5.

Penilaian Responden Terhadap Variabel Kinerja Pemasaran

\begin{tabular}{|c|c|c|c|c|c|c|c|c|c|}
\hline \multirow[t]{2}{*}{ No } & \multirow[t]{2}{*}{ Pernyataan } & \multicolumn{5}{|c|}{$\begin{array}{l}\text { Proporsi Jawaban } \\
\text { Responden (Orang) }\end{array}$} & \multirow[t]{2}{*}{ Jumlah } & \multirow{2}{*}{$\begin{array}{l}\text { Rata- } \\
\text { rata }\end{array}$} & \multirow[t]{2}{*}{ Kriteria } \\
\hline & & 1 & 2 & 3 & 4 & 5 & & & \\
\hline 1 & $\begin{array}{l}\text { Sejauh ini kami berhasil memenuhi target penjualan } \\
\text { setiap bulannya }\end{array}$ & 1 & 7 & 12 & 21 & 9 & 180 & 3.6 & Baik \\
\hline 2 & $\begin{array}{l}\text { Pertumbuhan pelanggan selalu mengalami } \\
\text { peningkatan sesuai yang diharapkan }\end{array}$ & 1 & 9 & 9 & 20 & 11 & 181 & 3.62 & Baik \\
\hline 3 & $\begin{array}{l}\text { Kami mendapatkan profit yang cukup sesuai dengan } \\
\text { biaya-biaya yang telah kami keluarkan. }\end{array}$ & 1 & 9 & 10 & 20 & 10 & 179 & 3.58 & Baik \\
\hline 4 & $\begin{array}{l}\text { Perusahaan kami sejauh ini berhasil membangun } \\
\text { hubungan yang baik dengan pelanggan sehingga } \\
\text { pelanggan melakukan pembelian secara berkala }\end{array}$ & 0 & 7 & 7 & 19 & 17 & 196 & 3.92 & Baik \\
\hline & Rata-rata & & & & & & & 3,68 & Baik \\
\hline
\end{tabular}

Sumber: Data diolah, 2020

Tingkat penjualan, tingkat pendapatan, jumlah pelanggan atau data lain yang terkait keberhasilan pemasarana produk atau jasa dari perusahaan merupakan beberapa factor yang dapat digunakan untuk mengukur atau menilai kinerja pemasaran dari suatu perusahaan. Tabel 5 menunjukkan bahwa secara umum responden setuju terhadap penilaian variabel kinerja pemasaran. Variabel kinerja pemasaran yang mempunyai nilai rata-rata terendah ada pada pernyataan "kami mendapatkan profit yang cukup sesuai dengan biaya-biaya yang telah kami keluarkan" dengan nilai rata-rata 3,58 yang berarti secara umum responden belem sepenuhnya mendapatkan profit yang cukup sesuai dengan biaya-biaya yang telah kami keluarkan. Variabel kinerja pemasaran yang mempunyai nilai rata-rata tertinggi ada pada pernyataan "perusahaan kami sejauh ini berhasil membangun hubungan yang baik dengan pelanggan sehingga pelanggan melakukan pembelian secara berkala", dengan nilai rata-rata 3,92 yang berarti secara umum perusahaan mereka sejauh ini berhasil membangun hubungan yang baik dengan pelanggan sehingga pelanggan melakukan pembelian secara berkala.

Penelitian ini menggunakan metode analisis PLS (Partial Least Square). 
Pengaruh Orientasi Pasar dan Inovasi Terhadap ...

Putu Aryanti Putri Kencana \& I Gusti Ayu Ketut Giantari

Terdapatdua evaluasi model mendasar dalam pengujian ini yaitu outer model dan inner model. Outer model adalah model pengukuran yang menghubungkan indikator dengan variabel latennya. Syarat validitas indikator diukur menggunakan convergent validity. Syarat reabilitas diukur menggunakan composite reability dan average variance extracted (AVE). Gambar 1 adalah diagram jalur evaluasi outer model.

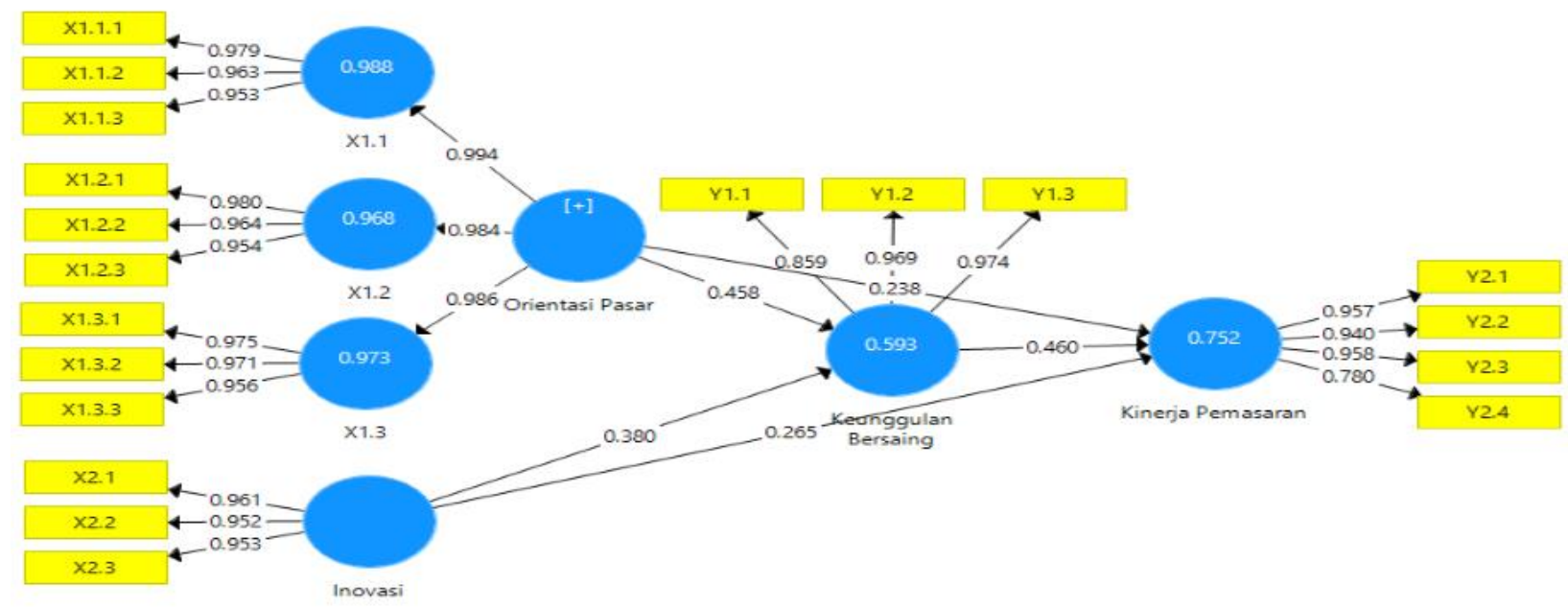

Gambar 1

Diagram Jalur Evaluasi Outer Model

Tabel 6.

Hasil Uji Validitas dengan Convergent Validity

\begin{tabular}{|c|c|c|c|}
\hline & Original Sample $(\mathrm{O})$ & T Statistics (|O/STDEV|) & P Values \\
\hline X1.1 <- Orientasi Pasar & 0.994 & 563.995 & 0.000 \\
\hline $\mathrm{X} 1.1 .1<-\mathrm{X} 1.1$ & 0.979 & 174.648 & 0.000 \\
\hline $\mathrm{X} 1.1 .2<-\mathrm{X} 1.1$ & 0.963 & 80.595 & 0.000 \\
\hline $\mathrm{X} 1.1 .3<-\mathrm{X} 1.1$ & 0.953 & 64.779 & 0.000 \\
\hline $\mathrm{X} 1.2<-$ Orientasi Pasar & 0.984 & 206.408 & 0.000 \\
\hline $\mathrm{X} 1.2 .1<-\mathrm{X} 1.2$ & 0.980 & 177.742 & 0.000 \\
\hline $\mathrm{X} 1.2 .2<-\mathrm{X} 1.2$ & 0.964 & 83.273 & 0.000 \\
\hline $\mathrm{X} 1.2 .3<-\mathrm{X} 1.2$ & 0.954 & 62.987 & 0.000 \\
\hline X1.3 <- Orientasi Pasar & 0.986 & 152.303 & 0.000 \\
\hline $\mathrm{X} 1.3 .1<-\mathrm{X} 1.3$ & 0.975 & 121.566 & 0.000 \\
\hline $\mathrm{X} 1.3 .2<-\mathrm{X} 1.3$ & 0.971 & 98.233 & 0.000 \\
\hline $\mathrm{X} 1.3 .3<-\mathrm{X} 1.3$ & 0.956 & 66.849 & 0.000 \\
\hline $\mathrm{X} 2.1<-$ Inovasi & 0.961 & 71.387 & 0.000 \\
\hline $\mathrm{X} 2.2<-$ Inovasi & 0.952 & 33.882 & 0.000 \\
\hline $\mathrm{X} 2.3<-$ Inovasi & 0.953 & 62.570 & 0.000 \\
\hline Y1.1<- Keunggulan Bersaing & 0.859 & 19.712 & 0.000 \\
\hline Y1.2<- Keunggulan Bersaing & 0.969 & 75.688 & 0.000 \\
\hline Y1.3<- Keunggulan Bersaing & 0.974 & 195.965 & 0.000 \\
\hline Y2.1 <- Kinerja Pemasaran & 0.957 & 69.151 & 0.000 \\
\hline Y $2.2<-$ Kinerja Pemasaran & 0.940 & 58.946 & 0.000 \\
\hline Y2.3 <- Kinerja Pemasaran & 0.958 & 78.921 & 0.000 \\
\hline Y2.4 <- Kinerja Pemasaran & 0.780 & 10.196 & 0.000 \\
\hline
\end{tabular}

Sumber: Data diolah, 2020 
Convergent validity dengan indikator refleksif dilihat dari korelasi antara skor indikator dengan skor variabelnya. Indikator dianggap reliabel jika memiliki nilai korelasi diatas 0,70. Tabel 6 menyatakan bahwa seluruh indikator telah memenuhi persyaratan convergent validity dan dinyatakan valid.

Discriminant validity dapat diukur menggunakan cross loading. Apabila nilai cross loading setiap indikator dari variabel yang bersangkutan lebih besar dibandingkan dengan cross loading variabel lain, maka indikator tersebut dikatakan valid. Tabel 7 menyatakan bahwa hasil komputasi discriminant validity indikator refleksif dengan nilai lebih dari 0,60. Berdasarkan Tabel 7 dapat dilihat bahwa bahwa nilai cross loading setiap indikator dari variabel yang bersangkutan lebih besar dibandingkan dengan cross loading variabel lainya sehingga dapat dijelaskan bahwa seluruh indikator pada setiap variabel adalah valid.

Metode lain untuk mengukur discriminant validity adalah dengan melihat nilai average variance extracted (AVE) untuk setiap variabel.

Tabel 8.

Hasil Average Varianced Extracted

\begin{tabular}{lc}
\hline \multicolumn{1}{c}{ Variabel Penelitian } & AVE \\
\hline Orientasi Pasar $\left(\mathrm{X}_{1}\right)$ & 0.977 \\
Inovasi $\left(\mathrm{X}_{2}\right)$ & 0.912 \\
Keunggulan Bersaing $\left(\mathrm{Y}_{1}\right)$ & 0.875 \\
Kinerja Pemasaran $\left(\mathrm{Y}_{2}\right)$ & 0.831 \\
\hline
\end{tabular}

Sumber: Data diolah, 2020

Berdasarkan Tabel 8 maka dapat dijelaskan bahwa nilai AVE variabel kinerja pemasaran, keunggulan bersaing, inovasi, dan orientasi pasar mempunyai nilai AVE tiap variabel dengan $>0,50$, yang artinya model dinyatakan baik.

Tabel 7.

Hasil Uji Validitas dengan Discriminant Validity

\begin{tabular}{ccccc}
\hline & Inovasi & Keunggulan Bersaing & Kinerja Pemasaran & Orientasi Pasar \\
\hline X1.1.1 & 0.650 & 0.699 & 0.714 & $\mathbf{0 . 9 6 7}$ \\
X1.1.2 & 0.615 & 0.673 & 0.652 & $\mathbf{0 . 9 5 9}$ \\
X1.1.3 & 0.680 & 0.686 & 0.757 & $\mathbf{0 . 9 5 1}$ \\
X1.2.1 & 0.714 & 0.735 & 0.766 & $\mathbf{0 . 9 6 0}$ \\
X1.2.2 & 0.674 & 0.705 & 0.699 & $\mathbf{0 . 9 5 2}$ \\
X1.2.3 & 0.728 & 0.712 & 0.795 & $\mathbf{0 . 9 4 1}$ \\
X1.3.1 & 0.603 & 0.640 & 0.669 & $\mathbf{0 . 9 6 4}$ \\
X1.3.2 & 0.578 & 0.647 & 0.649 & $\mathbf{0 . 9 5 1}$ \\
X1.3.3 & 0.624 & 0.668 & 0.724 & 0.947 \\
X2.1 & $\mathbf{0 . 9 6 1}$ & 0.644 & 0.726 & 0.607 \\
X2.2 & $\mathbf{0 . 9 5 2}$ & 0.657 & 0.682 & 0.660 \\
X2.3 & $\mathbf{0 . 9 5 3}$ & 0.686 & 0.732 & 0.694 \\
Y1.1 & 0.503 & $\mathbf{0 . 8 5 9}$ & 0.684 & 0.603 \\
Y1.2 & 0.687 & $\mathbf{0 . 9 6 9}$ & 0.770 & 0.714 \\
Y1.3 & 0.736 & $\mathbf{0 . 9 7 4}$ & 0.825 & 0.651 \\
Y2.1 & 0.699 & 0.725 & $\mathbf{0 . 9 5 7}$ & 0.745 \\
Y2.2 & 0.741 & 0.836 & $\mathbf{0 . 9 4 0}$ & 0.715 \\
Y2.3 & 0.726 & 0.787 & $\mathbf{0 . 9 5 8}$ & 0.615 \\
Y2.4 & 0.539 & 0.598 & $\mathbf{0 . 7 8 0}$ & \\
\hline
\end{tabular}

Sumber: Data diolah, 2020 
Tabel 9.

Hasil Uji Composite Reliability

\begin{tabular}{lrrc}
\hline \multicolumn{1}{c}{ Variabel } & $\begin{array}{c}\text { Composite } \\
\text { Reliability }\end{array}$ & $\begin{array}{c}\text { Cronbachs } \\
\text { Alpha }\end{array}$ & Keterangan \\
\hline Orientasi pasar (X1) & 0.992 & 0.988 & Reliabel \\
Inovasi (X2) & 0.969 & 0.952 & Reliabel \\
Keunggulan Bersaing (Y1) & 0.954 & 0.927 & Reliabel \\
Kinerja pemasaran (Y2) & 0.951 & 0.930 & Reliabel \\
\hline
\end{tabular}

Sumber: Data diolah, 2020

Uji reliabilitas variabel dilakukan dengan dengan menggunakan dua kriteria yaitu composite reliability dan cronbachs alpha. Berdasarkan Tabel 9 hasil output composite reliability maupun cronbachs alpha untuk variabel orientasi pasar, inovasi keunggulan bersaing, dan kinerja pemasaran semuanya diatas 0,60. Maka dapat disimpulkan bahwa variabel memiliki reliabilitas yang baik.

Pengujian inner model dilakukan

dengan melihat nilai evaluasi model struktural melalui $Q$-Square Predictive Relevance $\left(Q^{2}\right)$ yang merupakan pengukur seberapa baik observasi yang dilakukan memberikan hasil terhadap model penelitian. Perhitungan $Q$-Square menggunakan rumus $Q^{2}=1-\left(1-\mathrm{R}^{2}\right)\left(1-\mathrm{R}^{2}{ }_{2}\right)$ sehingga memerlukan nilai $R$-square yang berfungsi untuk mengetahui seberapa besar kontribusi variabel $\mathrm{X}$ terhadap variabel $\mathrm{Y}$. Gambar 2 adalah diagram jalur evaluasi inner model.

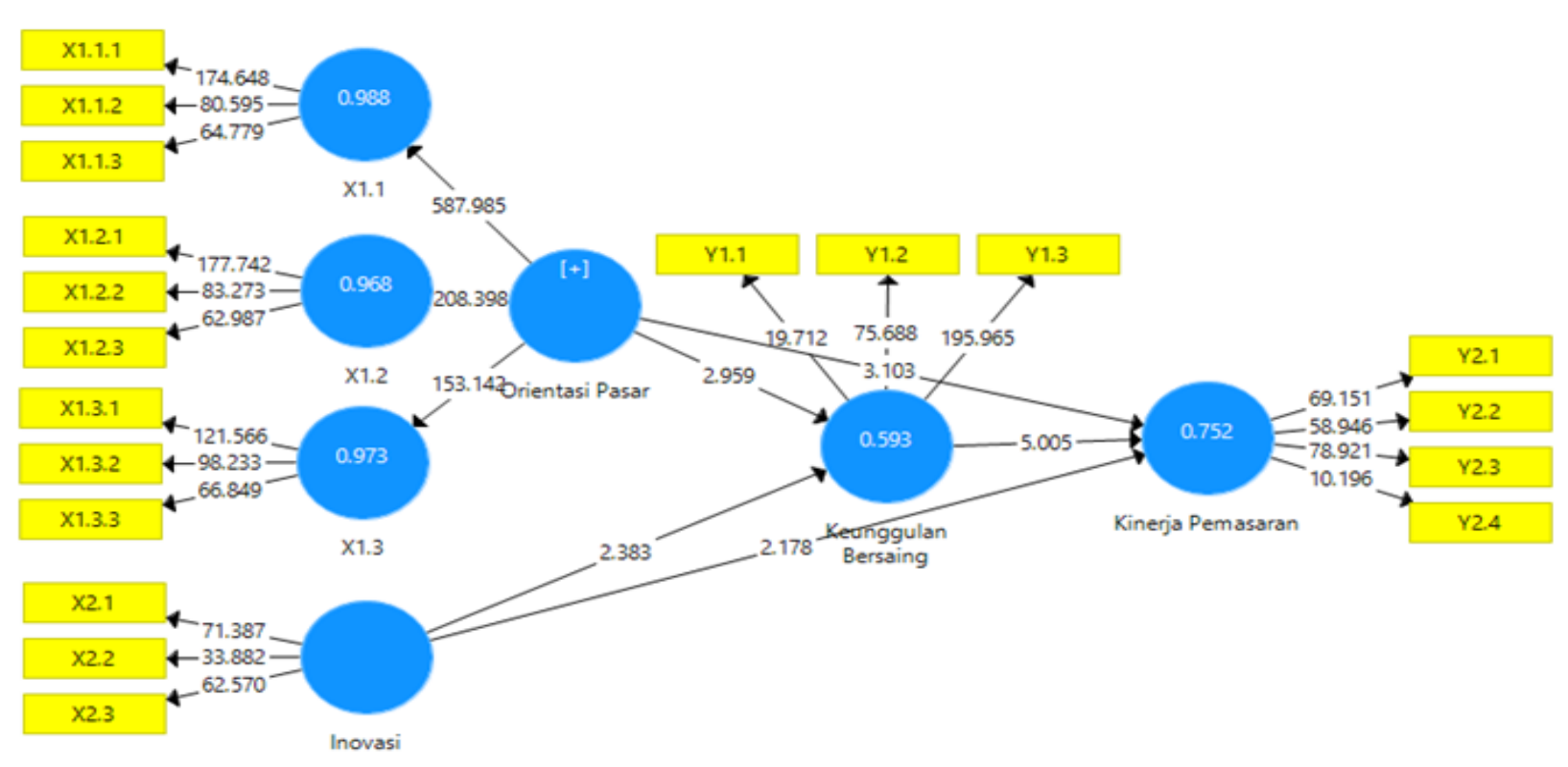

Gambar 2.

Diagram Jalur Evaluasi Inner Mode 
Dalam model dapat dilihat bahwa pengaruh orientasi pasar, inovasi dan keunggulan bersaing terhadap kinerja pemasaran memberikan nilai $R$-square seperti yang tercantum pada Tabel 10 .

Tabel 10.

Nilai $R$-square

\begin{tabular}{ll}
\hline Variabel & R Square \\
\hline Keunggulan bersaing & 0.593 \\
Kinerja pemasaran & 0.752 \\
\hline
\end{tabular}

Sumber: Data diolah, 2020

$$
\begin{aligned}
Q^{2} & =1-\left(1-\mathrm{R}^{2}\right)\left(1-\mathrm{R}^{2}{ }_{2}\right) \\
& =1-(0,407)(0,248) \\
& =1-0,101=0,899
\end{aligned}
$$

Hasil perhitungan $Q^{2}$ sebesar 0,899 , maka kesimpulannya adalah bahwa $88,9 \%$ variabel kinerja pemasaran pada UMKM pakaian jadi di Kota Denpasar dipengaruhi oleh orientasi pasar, inovasi, dan keunggulan bersaing, sedangkan faktor lain yang tidak tercantum dalam model penelitian memberikan pengaruh sebesar 10,1\%

Mengacu pada kriteria kuat lemahnya model berdasarkan nilai $Q$-Square Predictive Relevance $\left(Q^{2}\right)$, sebagaimana dikemukakan oleh Latan \& Ghozali (2015:80), apabila nilai $Q^{2}$ semakin mendekati 0, maka model penelitian dikatakan semakin tidak baik. Apabila semakin menjauh dari 0 dan semakin mendekat ke nilai 1 , artinya model penelitian semakin baik, sehingga model ini tergolong kuat.

Hipotesis diuji dengan menggunakan nilai path coefficients sebagai dasar. Dalam metode Partial Least Square (PLS), hipotesis diuji dengan menggunakan metode bootstrap. Hasil tersebut diuraikan pada Tabel 11. Berdasarkan Tabel 11 maka dapat dilihat pengaruh orientasi pasar terhadap kinerja pemasaran sebesar $+0,238$, dengan pvalues $0,003<0,05$ menunjukkan bahwa orientasi pasar memiliki pengaruh yang positif signifikan terhadap kinerja pemasaran pada UMKM pakaian jadi di Kota Denpasar sehingga $\mathrm{H}_{1}$ diterima. Penelitian yang dilakukan oleh Rokhman (2019); Udriyah et al., (2019); Nurhasanah \& Murwatiningsih (2018); Mulyani \& Mudiantono (2015) juga membuktikan bahwa orientasi pasar memiliki pengaruh yang positif dan signifikan terhadap kinerja pemasaran.

Tabel 11.

Nilai Path Coefficient

\begin{tabular}{lrrr}
\hline \multicolumn{1}{c}{ Variabel } & $\begin{array}{c}\text { Koefisien } \\
\text { Korelasi }\end{array}$ & t statistic & \multicolumn{1}{c}{$\boldsymbol{p}$ values } \\
\hline Orientasi Pasar -> Kinerja Pemasaran & 0.238 & 3.103 & 0.003 \\
Inovasi -> Kinerja Pemasaran & 0.265 & 2.178 & 0.034 \\
Orientasi Pasar -> Keunggulan Bersaing & 0.458 & 2.959 & 0.005 \\
Inovasi -> Keunggulan Bersaing & 0.380 & 2.383 & 0.021 \\
Keunggulan Bersaing -> Kinerja Pemasaran & 0.460 & 5.005 & 0.000 \\
\hline
\end{tabular}

Sumber: Data diolah, 2020 
Pengaruh Orientasi Pasar dan Inovasi Terhadap ...

Putu Aryanti Putri Kencana \& I Gusti Ayu Ketut Giantari

Hasil analisis pengaruh inovasi terhadap kinerja pemasaran sebesar $+0,265$, dengan $\mathrm{p}$ values $0,034<0,05$ menunjukkan bahwa inovasi berpengaruh positif signifikan terhadap kinerja pemasaran pada UMKM pakaian jadi di Kota Denpasar, apabila inovasi meningkat maka kinerja pemasaran akan mengalami peningkatan sebesar 0,265, sehingga $\mathrm{H}_{2}$ diterima. Penelitian yang dilakukan oleh Efrata et al., (2019); Satwika \& Dewi (2018); Nurhasanah \& Murwatiningsih (2018); Tawas \& Djodjobo (2014) juga membuktikan bahwa inovasi berpengaruh positif dan signifikan terhadap kinerja pemasaran.

Pengaruh orientasi pasar terhadap keunggulan bersaing sebesar $+0,458$, dengan $\mathrm{p}$ values $0,005<0,05$ menunjukkan bahwa orientasi pasar berpengaruh positif signifikan terhadap keunggulan bersaing pada UMKM pakaian jadi di Kota Denpasar, apabila orientasi pasar meningkat maka kinerja pemasaran akan mengalami peningkatan sebesar 0,458 , sehingga $\mathrm{H}_{3}$ diterima. Penelitian yang telah dilakukan oleh Satwika \& Dewi (2018); Herman et al., (2018); Sugiyarti (2015); Mulyani \& Mudiantono (2015) juga membuktikan bahwa orientasi pasar memiliki pengaruh positif dan signifikan terhadap keunggulan bersaing.

Pengujian hipotesis pada pengaruh inovasi terhadap keunggulan bersaing sebesar $+0,380$, dengan $\mathrm{p}$ values $0,021<0,05$ menunjukkan bahwa inovasi berpengaruh positif signifikan terhadap keunggulan bersaing pada UMKM pakaian jadi di Kota Denpasar, apabila inovasi meningkat maka kinerja pemasaran akan mengalami peningkatan sebesar 0,4380 , sehingga $\mathrm{H}_{4}$ diterima. Penelitian yang telah dilakukan sebelumnya oleh Alwi \& Handayani (2018); Sugiyarti (2015); Hartini (2012); Part (2010) juga membuktikan bahwa inovasi memiliki pengaruh positif dan signifikan terhadap keunggulan bersaing.

Pengaruh keunggulan bersaing terhadap kinerja pemasaran sebesar $+0,460$, dengan $\mathrm{p}$ values $0,000<0,05$ menunjukkan bahwa keunggulan bersaing berpengaruh positif signifikan terhadap kinerja pemasaran pada UMKM pakaian jadi di Kota Denpasar, apabila keunggulan bersaing meningkat maka kinerja pemasaran akan mengalami peningkatan sebesar 0,460 , sehingga $\mathrm{H}_{5}$ diterima. Penelitian yang dilakukan oleh Herman et al., (2018); Udriyah et al., (2019), Zaini et al., (2014); Tawas \& Djodjobo (2014) juga membuktikan bahwa keunggulan bersaing mempunyai pengaruh positif dan signifikan terhadap kinerja pemasaran.

\section{SIMPULAN DAN SARAN}

Hasil penelitian yang telah dilakukan memperoleh beberapa kesimpulan, yaitu orientasi pasar memiliki pengaruh positif signifikan terhadap kinerja pemasaran pada UMKM pakaian jadi di Kota Denpasar, yang artinya apabila orientasi pasar meningkat maka kinerja pemasaran akan semakin meningkat. Inovasi memiliki pengaruh positif signifikan terhadap kinerja pemasaran pada UMKM pakaian jadi di Kota Denpasar, yang artinya apabila inovasi semakin meningkat maka kinerja pemasaran juga akan meningkat. Orientasi pasar memiliki pengaruh positif signifikan terhadap 
Pengaruh Orientasi Pasar dan Inovasi Terhadap ...

Putu Aryanti Putri Kencana \& I Gusti Ayu Ketut Giantari

keunggulan bersaing pada UMKM pakaian jadi di Kota Denpasar, yang artinya apabila orientasi pasar meningkat maka keunggulan bersaing akan semakin meningkat. Inovasi mempunyai pengaruh positif signifikan terhadap keunggulan bersaing pada UMKM pakaian jadi di Kota Denpasar, yang artinya apabila inovasi meningkat maka keunggulan bersaing juga akan meningkat. Keunggulan bersaing mempunyai pengaruh positif dan signifikan terhadap kinerja pemasaran pada UMKM pakaian jadi di Kota Denpasar, yang artinya apabila keunggulan bersaing meningkat maka kinerja pemasaran akan semakin meningkat.

Saran yang dapat diberikan sesuai dengan hasil penelitian ini yaitu, pihak manajemen pada UMKM pakaian jadi di Kota Denpasar harus tetap meningkatkan orientasi pasar dan inovasi di dalam perusahaan agar bisa bersaing dengan perusahaan sejenis sehingga akan meningkatkan kinerja pemasaran pada UMKM pakaian jadi di Kota Denpasar. Pada aspek orientasi pasar perlu ditingkatkan lagi strategi dalam menganalisis kekurangan dan kelemahan pesaing sehingga dapat meningkatkan keunggulan bersaing dan kinerja pemasaran. Pada aspek inovasi perlu ditingkatkan lagi pengembangan produk dengan lebih baik sehinggaa produk memiliki ciri khas tersendiri dan dapat menarik konsumen dalam melakukan pembelian dan dapat meningkatkan keunggulan bersaing dan kinerja pemasaran.

Bagi peneliti selanjutnya diharapkan mampu menambah variabel- variabel yang dapat mempengaruhi kinerja pemasaran dan tidak hanya terbatas pada UMKM pakaian jadi di Kota Denpasar, sehingga mampu memberikan pandangan yang lebih luas dan dapat diimplementasikan secara umum.

\section{REFERENSI}

Alwi, T., \& Handayani, E. (2018). Keunggulan Bersaing UKM yang Dipengaruhi Oleh Orientasi Pasar Dan Inovasi Produk. Jurnal Pengembangan Wiraswasta, 20(3), 193. https://doi.org/10.33370/jpw.v20i3.256

Asashi, T. \& Sukaatmadja, G.P.I. (2017) Peran Inovasi Produk Memediasi Pengaruh Orientasi Pasar Terhadap Kinerja Pemasaran. E-Jurnal Manajemen Unud, 6(4), 1816-1845.

Lo, M. C., Azlan M. A., Ramayah, T. Wang, Y. C. (2015). Examining the Effects of Leadership, Market Orientation, and Leader Member Exchange (LMX) on Organizational Performance. Engineering Economica, 26(4), 409-421. https://doi.org/10.5755/j01.ee.26.4. 7656

CNBC Indonesia (2019). KPPI Mulai Investigasi Lonjakan Impor Tekstil ke RI. Retrieved from: https://www.cnbcindonesia.com/news/ 20190919191911-4-100814/kppi-mulaiinvestigasi-lonjakan-impor-tekstil-ke-ri

Dewi, S. T. (2006). Analisis Pengaruh Orientasi Pasar dan Inovasi Produk Terhadap Keunggulan Bersaing Untuk Meningkatkan Kinerja Pemasaran (Studi pada Industri Batik di Kota dan Kabupaten Pekalongan). Ekonomi Dan Bisnis.https://core.ac.uk/download/pdf/11715 776

Denpasarkota.go.id (2019). Industri Tekstil Mendominasi Pertumbuhan Industri di Bali. Retrieved from: https://www.denpasarkota.go. $\mathrm{id} /$ berita/baca/15321

Efrata, T. C., Radianto, W. E. D., Marlina, M. A. E., \& Budiono, S. C. (2019). The Impact of Innovation, Competitive Advantage, and Market Orientation on Firm's Marketing Performance in the Garment Industry in Indonesia. 100(Icoi), 399403.https://doi.org/10.2991/ico-i19.2019. 68

Ghozali, I. (2014). Structural Equation Modeling, Metode Alternatif dengan Partial Least Square (PLS). Edisi 4. Semarang: Badan Penerbit Universitas Diponegoro 
Pengaruh Orientasi Pasar dan Inovasi Terhadap ...

Putu Aryanti Putri Kencana \& I Gusti Ayu Ketut Giantari

Ginting, A. P., Giantari, I. G. A. K., \& Sudiksa, I. B. (2020). Peran Keunggulan Bersaing Dalam Memediasi Customer Relationship Management Terhadap Kinerja Pemasaran (Studi Kasus Pada Bank Perkreditan Rakyat se-Provinsi Bali). E-Jurnal Manajemen Universitas Udayana, 9(2), 508.https://doi.org/10.24843/ejmunud.2020.v 09.i02.p06

Hartanty, I. T., \& Ratnawati, A. (2013). Peningkatan kinerja pemasaran melalui optimalisasi keunggulan bersaing. Jurnal Ekonomi Dan Bisnis, 14(2), 72-89. http://jurnal.unissula.ac.id/index.php/ekobis/ar ticle/view/568

Hartini, S. (2012). Peran Inovasi: Pengembangan Kualitas Produk dan Kinerja Bisnis. Jurnal Manajemen Dan Kewirausahaan, 14(1), 8288. https://doi.org/10.9744/jmk.14.1.83-90

Herman, H., Hady, H., \& Arafah, W. (2018). International Journal of Science and Engineering Invention The Influence of Market Orientation and Product Innovation on the Competitive Advantage and Its Implication toward Small and Medium Enterprises (UKM) Performance. International Journal of Science and Engineering Invention, 04(19-21), 8-21. https://doi.org/10.23958/ijsei/vol04-i08/02

Jaworski, B. J., \& Kohli, A. K., (1993). Market Orientation: Antecedents and Consequences. Journal of Marketing. 57(3), 53-70. https://doi.org/10.2307/1251854

Kementrian Perindustrian Republik Indonesia (2019). Industri Pakaian Jadi Catatkan Pertumbuhan Paling Tinggi. Retrieved from: https://kemenperin.go.id/artikel/20641/Industr i-Pakaian-Jadi-Catatkan-Pertumbuhan-PalingTinggi

Mulyani, I. T., \& Mudiantono. (2015). Upaya Meningkatkan Kinerja Pemasaran Melalui Orientasi Pasar dan Orientasi Kewirausahaan dengan Inovasi sebagai Variabel Intervening (Studi Empiris pada Usaha Mikro Kecil dan Menengah Kota Semarang). Diponegoro Journal of Management, 4(3), 1-12. https://ejournal3.undip.ac.id/index.php/djom/a rticle/view/13215

Russell, S. N., \& Millar, H. H. (2014). Competitive Priorities of Manufacturing Firms in the Caribbean. IOSR Journal of Business and Management, $\quad$ 16(10), 72-82.
http://iosrjournals.org/iosr-jbm/papers/Vol16issue10/Version-1/I0161017282.pdf

Nurhasanah, N., \& Murwatiningsih, M. (2018). The Influence of Market Orientation, Learning Orientation, Innovation and Competitive Advantage to Improve Marketing Performance. Management Analysis Journal, 7(4), 458-468. https://doi.org/10.15294/maj. v7i4.25637

Rayadiani, S. (2015). Produksi Pakaian Jadi Indonesia. In Salim, Z., \& Ernawati, Info Komoditi Pakaian Jadi.Jakarta: AMP Press

Rokhman, M. T. N. (2019). Market Orientation to Improve Marketing Performance Through the Competitive Advantages of Batik Smes. Jurnal Aplikasi Manajemen, 17(3), 489-495. https://doi.org/10.21776/b.jam.2019.017.03.1 3

Safarnia, H., Akbari, Z., \& Abbasi, A. (2011). Review of Market Orientation and Competitive Advantage in the Industrial Estates Companies (Kerman, Iran): Appraisal of model by AMOS graphics. World Journal of Social Sciences, 1(5), 132-150.

Satwika, N. K. P., \& Dewi, N. M. W. K. (2018). Pengaruh Orientasi Pasar Serta Inovasi terhadap Keunggulan Kompetitif dan Kinerja Bisnis. E-Jurnal Manajemen Universitas Udayana, 7(3), 1481. https://doi.org/10.24843/ejmunud.2018. v7.i03.p13

Sugiyarti, G. (2015). Membangun Keunggulan Bersaing, Produk melalui Orientasi Pembelajaran, Orientasi Pasar dan Inovasi Produk (Studi Empiris Pada Industry Pakaian Jadi Skala Kecil Dan Menengah Di Kota Semarang). Jurnal Ilmiah Untag Semarang, 4(2), 110-123. http://jurnal.untagsmg.ac.id/ index.php/sa/article/view/157

Sugiyono. (2018). Metode Penelitian Bisnis Pendekatan Kuantitatif, Kualitatif, Kombinasi, dan $R \& D$. Bandung: Alfabeta.

Tawas, H., \& Djodjobo, C. (2014). Pengaruh Orientasi Kewirausahaan, Inovasi Produk, Dan Keunggulan Bersaing Terhadap Kinerja Pemasaran Usaha Nasi Kuning Di Kota Manado. Jurnal Riset Ekonomi, Manajemen, Bisnis Dan Akuntansi, 2(3), 1214-1224. https://ejournal.unsrat.ac.id/index.php/emba/ar ticle/view/5800

Udriyah, Tham, J., \& Azam, S. M. F. (2019). The Effects of Market Orientation and Innovation on Competitive Advantage and Business 
Pengaruh Orientasi Pasar dan Inovasi Terhadap ...

Performance of Textile Smes. Management Science Letters, 9(9), 1419-1428. https://doi.org/10.5267/j.msl.2019.5.009

Ulya, Z. (2019). Pengaruh Orientasi Pasar, Orientasi Pembelajaran dan Inovasi Produk terhadap Kinerja Pemasaran. In Jurnal Ekonomi Dan Bisnis Islam 4(2) https://doi.org/10.32505/v4i2.1254

Zaini, A., Hadiwidjojo, D., Rohman, F., \& Maskie, G. (2014). Effect Of Competitive Advantage As A Mediator Variable Of Entrepreneurship Orientation To Marketing Performance. IOSR Journal of Business and Management, 16(5), 05-10. https://doi.org/10.9790/487x16510510

Zhang, D. D., \& Bruning, E. (2011). Personal Characteristics and Strategic Orientation: Entrepreneurs in Canadia Manufacturing Companies. International Journal of Entrepreneurial Behavior and Research, 17(1), 82-103. https://doi.org/10.1108/13552 551111107525

Zhou, K. Z., Brown, J. R., \& Dev, C. S. (2009). Market Orientation, Competitive Advantage, and Performance: A Demand-Based Perspective. Journal of Business Research, 62(11), 10631070. https://doi.org/10.1016/j.jbusres.2008. 10.001 